\title{
( Financial Diagnosis Using CAMEL Model: aße Public versus Private Banks in Bangladesh
}

\author{
Aklima Akter \\ Student of IMBA, UIBE Business School, University of International Business and Economics, Beijing, CHINA \\ *E-mail for correspondence: aklima3rd@yahoo.com
}

Received: Nov 28, 2016;

Accepted: Jan 02, 2016;

Published: Apr 01, 2017

Source of Support: Nil

No Conflict of Interest: Declared

\begin{abstract}
The purpose of this paper is to empirically analyze the financial statement of two selected banks (One bank from the public sector and another one from the private) in Bangladesh during 2010-14. This study highlights ranking of two banks for their performance on CAMEL (Capital Adequacy; Asset Quality; Management Quality; Earnings Ability; and Liquidity) ratios. During the year Empirical results suggest that 2010-2014 NCCBL has scored better position of all the ratios except EPS, liquid assets to total assets and liquid assets to total deposits compared to JBL. By considering all of the parameters of CAMEL, NCCBL is the highest position assessed by the CAMEL Model because of its performance on the CAMEL ratios compared to JBL. JBL is lower position compared to NCCBL under the study because of its poor performance on the CAMEL ratios. The ultimate findings of the study indicate that JBL should improve the weaknesses of the CAMEL which ultimately improve the bank's overall performance. The findings of the paper will enable the practitioners and analysts to understand financial statement analysis in a depth manner.
\end{abstract}

Keywords: Financial Statement Analysis; Capital Adequacy; Asset Quality; Management Quality; Earnings Ability; and Liquidity

\section{INTRODUCTION}

Financial institutions are the essential components of the financial environment of any country. Banking institutions are the basic component of the various types of financial institutions. Banking sector plays a vital role to ensure the economic growth of a country by providing the flow of valuable funds and generating investments (Said and Tumin, 2011; Abdennour and Ben Khediri, 2010). There is a strong correlation between economic growth and financial system development. As the banking industry has enormously affected by the financial and economic crisis, an effective and sound banking system is essential for the sustainable growth of an economy (Kumar, 2016; Misra, 2015). Therefore, the financial performance measurement is an effective and efficient tool for measuring the financial health because strength financial position is not only important for the depositors but also a vital part of the shareholders, employees and economy (Mohiuddin, 2014; Misra and Aspal, 2013 \& Gupta, 2014). CAMEL model is an important technique for the performance diagnosis of the banks, which was first introduced in the U.S. in 1979.
CAMEL is a ratio-based model (Dang, 2011) which includes the following components:
* Capital adequacy;
* Asset quality;
* Management quality;
* Earning ability and;
* Liquidity.

Capital Adequacy indicates maintaining enough capital to cover any unexpected losses which preventing the bank from going into bankruptcy (Reddy, 2012). Therefore, it is essential for the bank to maintain a significant level of capital adequacy to prevent any unexpected loss and bank failure (Chen, 2003). Asset quality indicates the level of risky assets out of total assets of the bank. It measures the present and future financial strength of a bank. Poor asset quality leads to failure of the bank (Kumar, 2016; Dincer et al., 2011).

Management quality indicates the effective and efficient management of the banking activities. According to Misra and Aspal (2013), management efficiency ensures the activities to set to the changing environment which ultimately increases the capability of the bank. 
Earnings Ability indicates a bank's position, whether the bank is strong or weak $(\mathrm{Njoku}, 2013)$ and growth in earnings in future. Higher earning shows that bank's performance is healthy.

Liquidity indicates the ability of the banks to meet its financial obligations. An adequate liquidity ensures sufficient liquid funds (Roman and Sargu, 2013). Liquidity plays a key role because its shortage indicates the disability of the banks to make enough credit (Mebounou et al., 2015).

According to Kabir and Dey (2012), CAMEL rating system is widely used both locally and internationally for the financial analysis. For example, Douglas et al. (2014) find that CAMEL (Capital adequacy, Asset quality, Management competency, Earning quality, Liquidity) analysis is another approach for researchers to measure bank financial performance. Cole and Gunther (1998) find that CAMEL technique includes vital information for the financial diagnosis.

In Bangladesh, Bangladesh Bank as a Central Bank, which is a regulatory body, is calculating this rating till now (Majumder and Rahman, 2016). Very few authors used CAMEL techniques to measure the performance of the bank in Bangladesh, but they used a small sample. Because of this lack of research, it is considered that the present study has undertaken to fill up this gap. Therefore, in this paper, an attempt is made to evaluate the relative performance of the selected banks in Bangladesh using the CAMEL Model.

In order to achieve this, the study investigates the overall performance and a comparative analysis of capital adequacy; asset quality; management efficiency; earnings quality and liquidity of the two selected banks.

The rest of the paper is structured as follows: Section 2 provides a literature review of related prior studies. Section 3 describes the research methodology; the empirical analysis and findings of the study presented in Section 4 \& 5. Finally, in Section 6, the concluding remarks and recommendations are discussed.

\section{Related Prior Studies}

The prior studies by using CAMEL model for the diagnosis of performance from different perspectives are given below:

Majumder and Rahman (2016) explore the CAMEL model analysis of selected banks in Bangladesh, and they find there is a significant difference in the performance of the selected banks.

Tripathi et al. (2014) explore a study to compare the financial performance of Axis and Kotak Mahindra Bank. The analysis and t-test results are suggested that there is no significance difference between the Axis and Kotak Mahindra bank's financial performance, but the Kotak Mahindra bank performance is slightly less compared with Axis Bank.
Mishra \& Aspal (2013) employ the CAMEL model to investigate the performance of State Bank Group in India. The results indicate that no statistically significant difference between the CAMEL ratios.

Keovongvichith (2012) evaluate financial performance by using CAMEL framework. The results indicate that CAMEL is very useful tool to formulate strategies and policies for promoting a sound banking system.

Jaffar and Manarvi (2011) employ CAMEL model for measuring and comparing Islamic and conventional bank performance. Their findings suggest that the CAMEL rating system is a standard test for performance analysis of financial institutions.

Siva and Natarajan (2011) examine the performance of SBI Groups in India. The study shows that CAMEL scanning helps the bank to diagnose its financial health and alert the bank to take preventive steps for its sustainability.

Sangmi and Nazir (2010) find that banks were in a sound and satisfactory position so far as capital adequacy, asset quality, management capability and liquidity were concerned.

Freahat (2009) finds that Jordanian banks' performance was influenced by CAMEL ratios. Wirnkar \& Tanko (2008) examine the adequacy of CAMEL in determining the overall performance of Nigerian banks during (1997-2005). The results suggest that the inability of each component in CAMEL to congregate the full performance of a bank.

Bhayani (2006) employs the CAMEL model to investigate the performance of the new Indian private sector banks. The empirical results suggest that CAMEL is a very useful tool for measuring performance.

Nurazi and Evans (2005) employ CAMEL model, and the results suggest that adequacy ratio, asset quality, management, earnings, liquidity and bank size are statistically significant in determining bank failure.

Sarker (2005) examines the CAMEL model for regulation and supervision of Islamic banks in Bangladesh. The results of the study imply that the model is the best fit for the regulators to supervise and inspect the banks from an Islamic perspective.

Prasuna (2004) adopts the CAMEL model to investigate the performance of 65 Indian banks during the period 2003-04, and the results confirm that the competition was tough and consumers benefited from better service quality, innovative products, and better bargains.

Veni (2004) explores the capital adequacy requirement of commercial banks in India. The empirical results confirm that the rating agencies using CAMEL model lay emphasis on capital adequacy ratios of banks for rating the bank's certificate of deposits, fixed deposits, and bonds.

Barr et al. (2002) evaluate the productive efficiency and performance of US commercial banks. They conclude that CAMEL is a concise and vital tool for the regulatory bodies 
because it ensures a bank's healthy scenario by examining the various aspects of a bank based on a variety of information sources such as a financial statement, funding sources, macroeconomic data, budget and cash flow.

\section{Methodology}

The present study is prepared mainly by using secondary data. Data are collected from the annual report of the two banks of Bangladesh named Janata Bank Limited and NCC Bank Limited for the period ranging from 2010 to 2014; where the former is a public limited company, and the later one is a private limited company. Other secondary sources such as journals and electronic library resources of information are used in this study. CAMEL Model has been used to examine the financial strength, and for this purpose, the different perspectives of various ratios of CAMEL parameters are calculated then the average ratio of each parameter has taken to give ranks. Finally, the composite rankings have calculated based on the ranks of each parameter.

The methodology of this study is in a similar form of Majumder and Rahman (2016) where their studies based on seventeen ratios relating to CAMEL frameworks are given below at a glance:

Table I: Ratios used for measuring the CAMEL parameters

\begin{tabular}{|c|c|c|}
\hline Acronym & $\begin{array}{l}\text { CAMEL } \\
\text { Parameters }\end{array}$ & Ratios \\
\hline \multirow[t]{4}{*}{$\mathrm{C}$} & \multirow{4}{*}{$\begin{array}{l}\text { Capital } \\
\text { Adequacy }\end{array}$} & i) Capital Adequacy Ratio \\
\hline & & ii) Debt- Equity Ratio \\
\hline & & $\begin{array}{l}\text { iii) Loan \& Advances to } \\
\text { Total Assets Ratio }\end{array}$ \\
\hline & & $\begin{array}{l}\text { iv) Govt. Securities to Total } \\
\text { Investment Ratios }\end{array}$ \\
\hline \multirow[t]{3}{*}{ A } & \multirow[t]{3}{*}{$\begin{array}{l}\text { Asset } \\
\text { Quality }\end{array}$} & $\begin{array}{l}\text { i) } \% \text { of NPLs to Total } \\
\text { Loans }\end{array}$ \\
\hline & & $\begin{array}{l}\text { ii) Total Investment to } \\
\text { Total Assets Ratio }\end{array}$ \\
\hline & & $\begin{array}{l}\text { iii) } \% \text { of NPLs to Total } \\
\text { Assets }\end{array}$ \\
\hline \multirow[t]{3}{*}{$\mathrm{M}$} & \multirow[t]{3}{*}{$\begin{array}{l}\text { Management } \\
\text { Quality }\end{array}$} & $\begin{array}{l}\text { i) Loan \& Advances to } \\
\text { Deposit Ratios }\end{array}$ \\
\hline & & ii) Return on Equity ( $\mathrm{ROE}$ ) \\
\hline & & $\begin{array}{l}\text { iii) Net Profit per } \\
\text { Employee }\end{array}$ \\
\hline \multirow[t]{5}{*}{$\mathrm{E}$} & \multirow{5}{*}{$\begin{array}{l}\text { Earning } \\
\text { Ability }\end{array}$} & i) Return on Asset (ROA) \\
\hline & & ii) Net Profit Margin Ratio \\
\hline & & $\begin{array}{l}\text { iii) Interest Income to } \\
\text { Total Income Ratio }\end{array}$ \\
\hline & & $\begin{array}{l}\text { iv) Net Interest Margin to } \\
\text { Total Assets Ratio (Spread) }\end{array}$ \\
\hline & & $\begin{array}{l}\text { v) Earnings Per Share } \\
\text { (EPS) }\end{array}$ \\
\hline \multirow[t]{2}{*}{$\mathrm{L}$} & \multirow[t]{2}{*}{ Liquidity } & $\begin{array}{l}\text { i) Liquid Assets to Total } \\
\text { Assets Ratios }\end{array}$ \\
\hline & & $\begin{array}{l}\text { ii) Liquid Assets to Total } \\
\text { Deposits Ratio }\end{array}$ \\
\hline
\end{tabular}

Source: Majumder and Rahman (2016)

\section{EMPIRICAL ANALYSIS AND FINDINGS}

This section represents the various parameters and ratios of each parameter of CAMEL used to diagnose the comparative financial performance analysis of the present study:

\section{Capital Adequacy (C)}

The following four ratios are considered to assess the capital adequacy named as capital adequacy ratio, debtequity ratio, loan \& advances to total assets ratio and, government securities to total investment ratio.

\section{Capital Adequacy Ratio (CAR)}

Capital adequacy ratio is the ratio of TIER-I and TIER-II Capital to the total risk -weighted assets (RWA) which protect the bank from arising loss from weighted risk assets.

In Bangladesh, every bank required to meet the capital adequacy standard of $10 \%$ as per Bangladesh Bank guidelines. From the Table-II, it observes that NCCBL is maintained higher CAR than the standard level, but the average CAR of JBL showed lower than the standard level because the bank did not maintain the standard level of CAR in 2010 (9.19) and in 2012 (3.70). It represents that NCCBL has secured the higher position with higher average CAR compared to JBL. The high capital adequacy ratio of NCCBL indicates the stronger financial health of the bank and the more will be the protection of its investors.

Table: II

\begin{tabular}{|c|c|c|c|c|c|c|c|c|}
\hline & Name & \multicolumn{7}{|c|}{ Capital Adequacy Ratio (\%) } \\
\cline { 3 - 9 } S.N. & of Bank & 2010 & 2011 & 2012 & 2013 & 2014 & Average & Rank \\
\hline 1 & JBL & 9.19 & 10.20 & 3.70 & 10.27 & 10.30 & 8.73 & 2 \\
\hline 2 & NCCBL & 10.91 & 11.26 & 11.47 & 11.87 & 13.47 & 11.80 & 1 \\
\hline
\end{tabular}

\section{Debt-Equity Ratio}

Debt-equity ratio is the ratio of total liabilities to total shareholder's equity which measures the leverage of the banks. From the Table-III, it represents that NCCBL is on the higher position with the least average debt-equity ratio of 8.40 compared to JBL of 17.51 . The low debtequity ratio of the NCCBL indicates that it has more protection for the depositors and creditors. On the other hand, JBL's debt-equity ratio indicates less protection for the depositors and creditors.

Table: III

\begin{tabular}{|c|c|c|c|c|c|c|c|c|}
\hline & Name & \multicolumn{7}{|c|}{ Debt- Equity Ratio ( Times) } \\
\cline { 3 - 9 } S.N. & of Bank & 2010 & 2011 & 2012 & 2013 & 2014 & Average & Rank \\
\hline 1 & JBL & 15.93 & 13.61 & 28.25 & 14.79 & 14.95 & 17.51 & 2 \\
\hline 2 & NCCBL & 7.93 & 7.94 & 9.37 & 8.35 & 8.42 & 8.40 & 1 \\
\hline
\end{tabular}

Loan $\mathcal{E}$ Advances to Total Assets Ratio

Loan \& advances to total assets ratio is the ratio of total loan \& advances to total assets which indicate banks' lending responses against its assets. From the Table-IV, it observes that NCCBL is in the higher position with 
highest average loan \& advances to total assets ratio of 0.70 compared to JBL of 0.57 . The high ratio of NCCBL indicates good sign for the bank for producing better profitability compared to JBL.

Table: IV

\begin{tabular}{|c|c|c|c|c|c|c|c|c|}
\hline & Name & \multicolumn{6}{|c|}{ Loan \& Advances to Total Asset (Proportion) } \\
\cline { 3 - 9 } S.N. & of Bank & 2010 & 2011 & 2012 & 2013 & 2014 & Average & Rank \\
\hline 1 & JBL & 0.65 & 0.59 & 0.60 & 0.49 & 0.51 & 0.57 & 2 \\
\hline 2 & NCCBL & 0.76 & 0.7 & 0.64 & 0.71 & 0.67 & 0.70 & 1 \\
\hline
\end{tabular}

\section{Govt. Securities to Total Investment Ratio}

It is the ratio of total investment in government securities to total investment which indicates banks investment in high or low-risk projects. From the Table-V, it is found that NCCBL is on the higher position with higher average Govt. Securities to total investment ratio of 0.94 compared to JBL of 0.89 . Since, government securities are risk-free; the higher the ratio of NCCBL indicates lower risk is involved in a bank's investment compared to JBL.

Table: $\mathrm{V}$

\begin{tabular}{|c|c|c|c|c|c|c|c|c|}
\hline & Name & \multicolumn{6}{|c|}{ Govt. Securities to Total Investment (Proportion) } \\
\cline { 3 - 9 } S.N. & of Bank & 2010 & 2011 & 2012 & 2013 & 2014 & Average & Rank \\
\hline 1 & JBL & 0.91 & 0.89 & 0.85 & 0.91 & 0.91 & 0.89 & 2 \\
\hline 2 & NCCBL & 0.93 & 0.96 & 0.95 & 0.92 & 0.95 & 0.94 & 1 \\
\hline
\end{tabular}

Composite Ranking-Capital Adequacy (C)

The composite rankings of the various measures of the capital adequacy indicate the capital adequacy ability of the two banks together. Table-VI indicates NCCBL is the higher position with a group average of 1 compared to JBL average of 2. JBL scored the lower position due to its poor performance in Capital Adequacy, Debt-Equity, loan \& advances to total assets and Government securities to total investments ratio in compared to NCCBL.

Table: VI

\begin{tabular}{|c|c|c|c|c|c|c|c|c|c|c|}
\hline $\begin{array}{c}\text { Name of } \\
\text { Bank }\end{array}$ & $\begin{array}{c}\text { Capital } \\
\text { Adequacy }\end{array}$ & \multicolumn{2}{|c|}{$\begin{array}{c}\text { Debt- } \\
\text { Equity }\end{array}$} & \multicolumn{2}{c|}{$\begin{array}{c}\text { Loan \& } \\
\text { Advances to } \\
\text { Total Assets }\end{array}$} & \multicolumn{2}{c|}{$\begin{array}{c}\text { Govt. } \\
\text { Securities } \\
\text { to Total } \\
\text { Investments }\end{array}$} & \multicolumn{2}{c|}{$\begin{array}{c}\text { Composite } \\
\text { Rank }\end{array}$} \\
\cline { 2 - 13 } & Avg & Rank & Avg & Rank & Avg & Rank & Avg & Rank & Avg & Rank \\
\hline JBL & 8.73 & 2 & 17.51 & 2 & 0.57 & 2 & 0.89 & 2 & 2 & 2 \\
\hline NCCBL & 11.80 & 1 & 8.40 & 1 & 0.70 & 1 & 0.94 & 1 & 1 & 1 \\
\hline
\end{tabular}

\section{Asset Quality (A)}

The following three ratios are considered to assess the asset quality named as a percentage of non-performing loans to total loans, total investment to total assets ratio, a percentage of non-performing loans to total assets ratio.

\section{Percentage of NPLs to Total Loans}

It is the ratio of the total non-performing loans to total loans \& advances which indicate asset quality of the bank. From the Table-VII, it observes that NCCBL is on the higher position with a lower average ratio of 4.66 compared to JBL of 10.15. JBL's higher ratio indicates the bad quality of assets compared to NCCBL. The last three years ratio of JBL indicates a big amount of loan are a non-performing loan which is a bad sign for the bank.
Table: VII

\begin{tabular}{|c|c|c|c|c|c|c|c|c|}
\hline & Name & \multicolumn{6}{|c|}{ Percentage of NPLs to Total Loans } \\
\cline { 3 - 9 } S.N. & of Bank & 2010 & 2011 & 2012 & 2013 & 2014 & Average & Rank \\
\hline 1 & JBL & 4.96 & 5.56 & 17.42 & 11.12 & 11.69 & 10.15 & 2 \\
\hline 2 & NCCBL & 2.25 & 2.66 & 5.46 & 5.51 & 7.41 & 4.66 & 1 \\
\hline
\end{tabular}

Total Investment to Total Assets Ratio

This ratio can be calculated by dividing the total investments by the total assets which indicate banks policy relating to its investments. A High ratio indicates conservative policy and a low ratio indicates aggressive policy. In table-VIII, NCCBL is on the good possession with the lower average of 0.19 compared to JBL of 0.25. The higher ratio of JBL indicates a conservative policy of the bank compared to NCCBL.

Table: VIII

\begin{tabular}{|c|c|c|c|c|c|c|c|c|}
\hline & Name & \multicolumn{6}{|c|}{ Total Investment to Total Asset (Proportion) } \\
\cline { 3 - 9 } S.N. & of Bank & 2010 & 2011 & 2012 & 2013 & 2014 & Average & Rank \\
\hline 1 & JBL & 0.17 & 0.21 & 0.21 & 0.33 & 0.31 & 0.25 & 2 \\
\hline 2 & NCCBL & 0.13 & 0.20 & 0.25 & 0.16 & 0.20 & 0.19 & 1 \\
\hline
\end{tabular}

Percentage of NPLs to Total Assets

The total non-performing loans to total assets measure the credit risk. In table-IX, NCCBL is on the good position with a lower average of 3.19 compared to JBL of 5.65. The lower ratio of NCCBL indicates better efficiency in assessing the credit risk and recovering the debt. JBL scored with a higher ratio of 5.65 which indicates a higher risk is involved in a bank's loan recovery compared to NCCBL.

Table: IX

\begin{tabular}{|c|c|c|c|c|c|c|c|c|}
\hline & Name & \multicolumn{6}{|c|}{ \% of NPLs to Total Asset } \\
\cline { 3 - 9 } S.N. & of Bank & 2010 & 2011 & 2012 & 2013 & 2014 & Average & Rank \\
\hline 1 & JBL & 3.24 & 3.26 & 10.41 & 5.42 & 5.94 & 5.65 & 2 \\
\hline 2 & NCCBL & 1.71 & 1.87 & 3.47 & 3.92 & 4.98 & 3.19 & 1 \\
\hline
\end{tabular}

Composite Ranking-Asset Quality (A)

The composite rankings of the various measures of the asset quality indicate the asset quality ability of the two banks together. Table- $X$ indicates NCCBL is the first position with a group average of 1.00 followed by JBL. JBL scored the lower position due to its poor performance in NPLs to total loans, total investments to total assets and NPLs to total assets ratios.

Table: $X$

\begin{tabular}{|c|c|c|c|c|c|c|c|c|}
\hline $\begin{array}{c}\text { Name } \\
\text { of Bank }\end{array}$ & \multicolumn{2}{|c|}{$\begin{array}{c}\text { \% of NPLs to } \\
\text { Total Loans }\end{array}$} & $\begin{array}{c}\text { Total Investment } \\
\text { to Total Assets } \\
\text { Ratio }\end{array}$ & $\begin{array}{c}\% \text { of NPLs to } \\
\text { Total Assets }\end{array}$ & \multicolumn{2}{|c|}{$\begin{array}{c}\text { Composite } \\
\text { Rank }\end{array}$} \\
\cline { 2 - 9 } & Avg & Rank & Avg & Rank & Avg & Rank & Avg & Rank \\
\hline JBL & 10.15 & 2 & 0.25 & 2 & 5.65 & 2 & 2 & 2 \\
\hline NCCBL & 4.66 & 1 & 0.19 & 1 & 3.19 & 1 & 1 & 1 \\
\hline
\end{tabular}

\section{Management Quality (M)}

The following three ratios are considered to assess the management quality named as loan \& advances to deposit ratio, return on equity, and net profit per employee. 


\section{Loan $\mathcal{E}$ Advances to Deposit Ratios}

It can be calculated by dividing the total loan \& advances by the total deposits which indicate the conversion ability of the bank's deposits into advances. From the Table-XI, it observes that NCCBL is on the higher position with higher average loan \& advances to total deposits ratio of 0.88 compared to JBL of 0.69 . The high ratio of NCCBL indicates its management high ability to convert its deposits into higher earning advances compared to JBL.

Table: XI

\begin{tabular}{|c|c|c|c|c|c|c|c|c|}
\hline & Name & \multicolumn{5}{|c|}{ Loan \& Advances to Deposit (Proportion) } \\
\cline { 3 - 9 } S.N. & of Bank & 2010 & 2011 & 2012 & 2013 & 2014 & Average & Rank \\
\hline 1 & JBL & 0.79 & 0.71 & 0.75 & 0.60 & 0.62 & 0.69 & 2 \\
\hline 2 & NCCBL & 0.93 & 0.90 & 0.82 & 0.90 & 0.86 & 0.88 & 1 \\
\hline
\end{tabular}

Return on Equity (ROE)

It is the ratio of total net profit after tax to total shareholder's equity which indicates the ability to earn by per taka invested. In table-XII, NCCBL is in the better position with a higher average of $15.11 \%$ compared to JBL, while JBL scored negative percentage $(4.08 \%)$ because of its negative return in 2012 which is due to lower amount of interest income earned from loan \& advances against of interest paid on deposit and borrowings.

Table: XII

\begin{tabular}{|c|c|c|c|c|c|c|c|c|}
\hline & Name & \multicolumn{7}{|c|}{ Return on Equity (ROE) (\%) } \\
\cline { 3 - 9 } S.N. & of Bank & 2010 & 2011 & 2012 & 2013 & 2014 & Average & Rank \\
\hline 1 & JBL & 24.07 & 14.74 & $(94.62)$ & 25.73 & 9.66 & $(4.08)$ & 2 \\
\hline 2 & NCCBL & 25.35 & 18.98 & 11.81 & 8.96 & 10.46 & 15.11 & 1 \\
\hline
\end{tabular}

\section{Net Profit per Employee}

It is the ratio of the net profit after tax to total number of employees which indicate earnings ability by per employee using their efficiency. In table-XIII, NCCBL is in the better position with a higher average of 0.97 followed by JBL of 0.10 . The high ratio of EBL indicates higher the efficiency of management compared to JBL. JBL scored the lower position; of course, one of the reasons is negative return in 2012.

Table: XIII

\begin{tabular}{|c|c|c|c|c|c|c|c|c|}
\hline & Name & \multicolumn{5}{|c|}{ Net Profit per Employee (in Million Tk) } \\
\cline { 3 - 9 } S.N. & of Bank & 2010 & 2011 & 2012 & 2013 & 2014 & Average & Rank \\
\hline 1 & JBL & 0.38 & 0.30 & $(1.08)$ & 0.62 & 0.26 & 0.10 & 2 \\
\hline 2 & NCCBL & 1.46 & 1.13 & 0.79 & 0.54 & 0.93 & 0.97 & 1 \\
\hline
\end{tabular}

Composite Ranking- Management Quality (M)

The composite rankings of the various measures of the management quality indicate the management quality ability of the two banks together. Table-XIV indicates NCCBL is the first position with a group average of 1 followed by JBL of 2. JBL scored the lower position due to its poor performance in total loan \& advances to total deposits, return on equity and net profit per employee ratios compared to NCCBL.
Table: XIV

\begin{tabular}{|c|c|c|c|c|c|c|c|c|}
\hline $\begin{array}{c}\text { Name } \\
\text { of Bank }\end{array}$ & \multicolumn{2}{|c|}{$\begin{array}{c}\text { Loan \& } \\
\text { Advances to } \\
\text { Deposit Ratios }\end{array}$} & \multicolumn{2}{|c|}{$\begin{array}{c}\text { Return on } \\
\text { Equity (ROE) }\end{array}$} & $\begin{array}{c}\text { Net Profit } \\
\text { per } \\
\text { Employee }\end{array}$ & $\begin{array}{c}\text { Composite } \\
\text { Rank }\end{array}$ \\
\cline { 2 - 9 } & Avg & Rank & Avg & Rank & Avg & Rank & Avg & Rank \\
\hline JBL & 0.69 & 2 & $(4.08)$ & 2 & 0.10 & 2 & 2 & 2 \\
\hline NCCBL & 0.88 & 1 & 15.11 & 1 & 0.97 & 1 & 1 & 1 \\
\hline
\end{tabular}

\section{Earning Ability (E)}

The following five ratios are considered in the present study to assess the earning ability of the selected banks:

\section{Return on Asset (ROA)}

It is the ratio of the total net profit after tax to total assets which indicates earnings ability by per unit of an asset. In table-XV, NCCBL is on the higher position with a higher average of 1.63 followed by JBL of 0.30 . The higher ratio of NCCBL means better managerial performance and efficient utilization of the assets of the Bank compared to JBL. On the other hand, JBL scored is the indicator of inefficient use of assets which can be observed in 2012 with a negative return.

Table: XV

\begin{tabular}{|c|c|c|c|c|c|c|c|c|}
\hline & Name & \multicolumn{6}{|c|}{ Return on Asset (ROA) (\%) } \\
\cline { 3 - 9 } S.N. & of Bank & 2010 & 2011 & 2012 & 2013 & 2014 & Average & Rank \\
\hline 1 & JBL & 1.42 & 1.01 & $(3.19)$ & 1.63 & 0.61 & 0.30 & 2 \\
\hline 2 & NCCBL & 2.84 & 2.12 & 1.14 & 0.92 & 1.11 & 1.63 & 1 \\
\hline
\end{tabular}

\section{Net Profit Margin Ratio}

It is the ratio of the net profit after tax to the total income which indicates efficiency in operations. From the TableXVI, it observes that NCCBL is the better position with a higher average ratio of $12.95 \%$ followed by JBL of $3.64 \%$. The high ratio of NCCBL indicates the better operational efficiency of the bank than JBL. JBL's ratio is decreasing from 2010 to 2014 except in 2013, so, it's not a good sign for the bank.

Table: XVI

\begin{tabular}{|c|c|c|c|c|c|c|c|c|}
\hline & Name & \multicolumn{7}{|c|}{ Net Profit Margin ratio (\%) } \\
\cline { 3 - 9 } S.N. & of Bank & 2010 & 2011 & 2012 & 2013 & 2014 & Average & Rank \\
\hline 1 & JBL & 16.03 & 10.94 & $(32.88)$ & 17.34 & 6.76 & 3.64 & 2 \\
\hline 2 & NCCBL & 23.34 & 15.79 & 9.18 & 7.00 & 9.46 & 12.95 & 1 \\
\hline
\end{tabular}

Interest Income to Total Income Ratio

It is the ratio of total interest income to total income which indicates the ability of earnings from lending. In table-XVII, NCCBL is in the better position with a higher average of 0.73 followed by JBL of 0.64 . So, the ratios indicated that NCCBL has more capability in generating income from its lending business.

Table: XVII

\begin{tabular}{|c|c|c|c|c|c|c|c|c|}
\hline & Name & \multicolumn{3}{|c|}{ Interest Income to Total Income (Proportion) } \\
\cline { 3 - 9 } S.N. & of Bank & 2010 & 2011 & 2012 & 2013 & 2014 & Average & Rank \\
\hline 1 & JBL & 0.62 & 0.65 & 0.69 & 0.66 & 0.60 & 0.64 & 2 \\
\hline 2 & NCCBL & 0.69 & 0.69 & 0.75 & 0.75 & 0.76 & 0.73 & 1 \\
\hline
\end{tabular}




\section{Net Interest Margin to Total Assets Ratio / (Spread)}

It is the ratio of the net interest margin to total assets which indicates net interest earnings by per unit of the asset. In table-XVIII, NCCBL is in the better position with a higher average of $2.00 \%$ followed by JBL of $1.05 \%$.

Table: XVIII

\begin{tabular}{|c|c|c|c|c|c|c|c|c|}
\hline & Name & \multicolumn{6}{|c|}{ Net Interest Margin to Total Asset (Spread) (\%) } \\
\cline { 3 - 9 } S.N. & of Bank & 2010 & 2011 & 2012 & 2013 & 2014 & Average & Rank \\
\hline 1 & JBL & 2.05 & 1.90 & 1.32 & 0.34 & $(.36)$ & 1.05 & 2 \\
\hline 2 & NCCBL & 2.98 & 1.60 & 1.78 & 1.64 & 1.98 & 2.00 & 1 \\
\hline
\end{tabular}

Earnings per Share (EPS)

It is the ratio of the net profit after tax after deducting preference dividend to the total number of equity shares which indicates the ability of earnings by per share. Table-XIX shows that JBL is the higher position in earning per share compared to NCCBL though JBL had a negative return in 2012.

Table: XIX

\begin{tabular}{|c|c|c|c|c|c|c|c|c|}
\hline & Name & \multicolumn{6}{|c|}{ Earnings Per Share (EPS) ( Tk) } \\
\cline { 2 - 9 } S.N. & of Bank & 2010 & 2011 & 2012 & 2013 & 2014 & Average & Rank \\
\hline 1 & JBL & 69.66 & 43.46 & $(148)$ & 86.31 & 19.92 & 14.27 & 1 \\
\hline 2 & NCCBL & 5.33 & 3.7 & 2.06 & 1.49 & 1.87 & 2.89 & 2 \\
\hline
\end{tabular}

Composite Ranking- Earning Ability (E)

The composite rankings of the various measures of the earnings ability indicate the earnings ability of the two banks together. Table-XX indicates NCCBL is a better position with a group average of 1.2 compared to JBL of 1.8. JBL scored lower position due to its poor performance in ROA, net profit margin ratio, Interest income to total income ratio, and spread compared to NCCBL.

Table: XX

\begin{tabular}{|c|c|c|c|c|c|c|c|c|c|c|c|c|}
\hline \multirow{2}{*}{$\begin{array}{c}\text { Name } \\
\text { of } \\
\text { Bank }\end{array}$} & \multicolumn{2}{|c|}{ ROA } & \multicolumn{2}{|c|}{$\begin{array}{c}\text { Net Profit } \\
\text { Margin }\end{array}$} & \multicolumn{2}{|c|}{$\begin{array}{l}\text { Interest Income } \\
\text { to Total Income }\end{array}$} & \multicolumn{2}{|c|}{ Spread } & \multicolumn{2}{|c|}{ EPS } & \multicolumn{2}{|c|}{$\begin{array}{c}\text { Compo } \\
\text { site Rank }\end{array}$} \\
\hline & Avg & Rank & Avg & Rank & Avg & Rank & Avg & Rank & Avg & Rank & Avg & Rank \\
\hline $\mathrm{JBL}$ & 0.30 & 2 & 3.64 & 2 & 0.6 & 2 & 1.05 & 2 & \begin{tabular}{|l}
14.27 \\
\end{tabular} & 1 & 1.8 & 2 \\
\hline NCCBL & 1.63 & 1 & 12.95 & 1 & 0.73 & 1 & 2.00 & 1 & 2.89 & 2 & 1.2 & 1 \\
\hline
\end{tabular}

\section{Liquidity (L)}

The following two ratios are considered to assess the liquidity named as liquid assets to total assets ratio and liquid assets to total deposits ratio.

\section{Liquid Assets to Total Assets Ratio}

It is the ratio of the total liquid assets to the total assets which indicates the liquidity capacity against per unit of assets. In table-XXI, JBL is on higher position with a higher average of 0.09 compared to NCCBL of 0.07 .

Table: XXI

\begin{tabular}{|c|c|c|c|c|c|c|c|c|}
\hline & Name & \multicolumn{4}{|c|}{ Liquid Asset to Total Asset (Proportion) } \\
\cline { 2 - 8 } S.N. & of Bank & 2010 & 2011 & 2012 & 2013 & 2014 & Average & Rank \\
\hline 1 & JBL & 0.08 & 0.12 & 0.10 & 0.08 & 0.09 & 0.09 & 1 \\
\hline 2 & NCCBL & 0.08 & 0.07 & 0.07 & 0.07 & 0.08 & 0.07 & 2 \\
\hline
\end{tabular}

Liquid Assets to Total Deposits Ratio

This is the ratio of total liquid assets to total deposits which indicates the ability to meet depositor's obligations.
In table-XXII, JBL is in a better position with a higher average of 0.11 followed by NCCBL of 0.09 .

Table: XXII

\begin{tabular}{|c|c|c|c|c|c|c|c|c|}
\hline & Name & \multicolumn{4}{|c|}{ Liquid Asset to Total Deposit (Proportion) } \\
\cline { 3 - 8 } S.N & of Bank & 2010 & 2011 & 2012 & 2013 & 2014 & Average & Rank \\
\hline 1 & JBL & 0.10 & 0.14 & 0.12 & 0.10 & 0.11 & 0.11 & 1 \\
\hline 2 & NCCBL & 0.10 & 0.09 & 0.09 & 0.09 & 0.10 & 0.09 & 2 \\
\hline
\end{tabular}

Composite Ranking-Liquidity $(L)$

The composite rankings of the various measures of the liquidity indicate the liquidity position of the two banks together. Table-XXIII indicates JBL is a better position with a group average of 1.00 followed by NCCBL with an average of 2. NCCBL scored lower position due to poor performance in Liquid Assets to Total Assets and Liquid Assets to Total Deposits ratios compared to JBL.

Table: XXIII

\begin{tabular}{|c|c|c|c|c|c|c|}
\hline $\begin{array}{c}\text { Name of } \\
\text { Bank }\end{array}$ & \multicolumn{2}{|c|}{$\begin{array}{c}\text { Liquid Assets } \\
\text { to Total } \\
\text { Assets Ratio }\end{array}$} & \multicolumn{2}{|c|}{$\begin{array}{c}\text { Liquid Assets } \\
\text { to Total } \\
\text { Deposits Ratio }\end{array}$} & \multicolumn{2}{|c|}{$\begin{array}{c}\text { Composite } \\
\text { Rank }\end{array}$} \\
\cline { 2 - 7 } & Avg & Rank & Avg & Rank & Avg & Rank \\
\hline JBL & 0.09 & 1 & 0.11 & 1 & 1 & 1 \\
\hline NCCBL & 0.07 & 2 & 0.09 & 2 & 2 & 2 \\
\hline
\end{tabular}

\section{Composite Rankings-Overall Comparative}

\section{Performance}

Table-XXIV shows the composite ranking of the two banks for the period of 2010-2014. By considering all the ratios under all the sub-parameter of CAMEL, it observes that NCCBL has better performance compared to JBL. It also can see that under all parameters of the CAMEL except liquidity, NCCBL is better positioned compared to JBL. NCCBL has scored better position of all the ratios except EPS, liquid assets to total assets and liquid assets to total deposits compared to JBL.

Table: XXIV

\begin{tabular}{|c|c|c|c|c|c|c|c|}
\hline $\begin{array}{c}\text { Name } \\
\text { of Bank }\end{array}$ & $\begin{array}{c}\text { Capital } \\
\text { Adequacy } \\
(\mathrm{C})\end{array}$ & $\begin{array}{c}\text { Asset } \\
\text { Quality } \\
(\mathrm{A})\end{array}$ & $\begin{array}{c}\text { Management } \\
\text { Efficiency } \\
(\mathrm{M})\end{array}$ & $\begin{array}{c}\text { Earnings } \\
\text { Ability } \\
(\mathrm{E})\end{array}$ & $\begin{array}{c}\text { Liquidity } \\
\text { (L) }\end{array}$ & Average & Rank \\
\hline JBL & 2 & 2 & 2 & 2 & 1 & 1.8 & 2 \\
\hline NCCBL & 1 & 1 & 1 & 1 & 2 & 1.2 & 1 \\
\hline
\end{tabular}

\section{Conclusion and Recommendations}

The growth of the banking industry influences the Economic development of the same country. The current study has been conducted to examine the economic sustainability of the two banks in Bangladesh by using a CAMEL approach during 2010-14.During the year 20102014 NCCBL has scored better position of all the ratios except EPS, liquid assets to total assets and liquid assets to total deposits compared to JBL. By considering all of the parameters of CAMEL, it observes that NCCBL is the highest position assessed by the CAMEL Model because of its strong performance on the CAMEL ratios compared to JBL. JBL is lower position compared to NCCBL under the study because of its poor performance on the CAMEL ratios. From the capital adequacy ratios, it observes that 
JBL is not maintained the standard level of capital adequacy as mentioned by the central bank. The JBL policy maker should think about it. From 2012, JBL nonperforming loan increases due to sanctioning loan in the unworthy sector and bad recovery of loans. As consequences, JBL got a negative return in 2012 and also return decreased to in 2014. Since non-performing loan creates risk for the bank, it ultimately affects to the profitability of the bank. So, JBL should reduce the amount of non-performing loans by giving loans to worthy projects and the loan division of the bank should take a proper step so that it can recover the debt within due time. The ultimate aim of the study indicates that JBL should improve the weaknesses of the lower ratios of the CAMEL which ultimately improve the bank's overall performance. The main limitations of the study are using a small sample, but it will enable to the policy maker to understand the financial statement analysis in a depth manner.

\section{REFERENCES}

Abdennour, F. and Ben Khediri, K. (2010), "Bank supervision and bank profitability: the case of MENA countries," Int. J. Monetary Economics and Finance, Vol. 3, No. 4, pp.316-329.

Barr, R.S., Killgo, K.A., Siems, T.F. and Zimmel, S. (2002), "Evaluating the productive efficiency and performance of US commercial banks," Managerial Finance, Vol. 28, No. 8, pp.3-25.

Bhayani, S. (2006), "Performance of the new Indian private sector banks: A Comparative Study," Journal of Management Research, Vol. 5, No. 11, pp.53-70.

Chen, J. (2003), “Capital adequacy of Chinese banks: evaluation and enhancement, "Journal of Banking Regulation, Vol. 4, No. 4, pp. 320-327.

Cole, R.A. and Gunther, J.W. (1998), "Predicting bank failures: A comparison of on-and off-site monitoring systems," Journal of Financial Services Research, Vol. 13, No. 2, pp.103-117.

Dang, U. (2011), "The CAMEL rating system in banking supervision. A case study," available at: http://www.theseus.fi/bitstream/handle/10024/38344/D ang_Uyen.pdf?...1 (accessed 13 January 2015.

Dincer, H., Gencer, G., Orhan, N. and Sahinbas, K. (2011), “A performance evaluation of the Turkish banking sector after the global crisis via CAMELS ratios," Procedia-Social and Behavioral Sciences, Vol. 24, pp.1530-1545.

Douglas, E., Lont, D. and Scott, T. (2014), "Finance company failure in New Zealand during 2006-2009: Predictable failures?," Journal of Contemporary Accounting \& Economics, Vol. 10, No. 3, pp.277-295.

Freahat, K.I.A.A. (2009), “Evaluating Performance of Commercial Banks: An Empirical Study in Jordan (20042008)," Ph.D. diss, Universiti Utara Malaysia.

Gupta, P.K. (2014), "An analysis of Indian public sector banks using CAMEL approach", IOSR Journal of Business and Management, Vol. 16, No. 1, pp.94-102.

Jaffar, M. and Manarvi, I. (2011), "Performance comparison of Islamic and Conventional banks in Pakistan," Global Journal of Management and Business Research, Vol. 11, No. 1, pp. 60-66.
Kabir, M.A. and Dey, S. (2012), "Performance analysis through CAMEL rating: A comparative study of selected private commercial banks in Bangladesh," Journal of Politics \& Governance, Vol. 1, No. 2/3, pp.16-25.

Keovongvichith, P. (2012), "An analysis of the recent financial performance of the Laotian banking sector during 20052010," International Journal of Economics and Finance, Vol. 4, No. 4, pp.148.

Kumar, V. (2016), "Evaluating the financial performance and financial stability of national commercial banks in the UAE," Int. J. Business and Globalisation, Vol. 16, No. 2, pp.109-128.

Majumder, M.T.H. and Rahman, M.M. (2016), "A CAMEL Model Analysis of Selected Banks in Bangladesh," International Journal of Business and Technopreneurship, Vol. 6, No. 2, pp. 233-266.

Mebounou, T.G.C., Karan, M.B. and Dannon, H. (2015), "Liquidity and bank profitability in WAEMU zone: a panel data analysis," Afro-Asian J. Finance and Accounting, Vol. 5, No. 2, pp.113-134.

Mishra, S. K. and Aspal, P.K. (2013), "A Camel Model Analysis of State Bank Group," World Journal of Social Sciences, Vol. 3, No. 4, pp. $36-55$.

Misra, S.D. (2015), "Determinants of bank profitability in India", Int. J. Indian Culture and Business Management, Vol. 10, No. 2, pp.193-212.

Mohiuddin, G. (2014), "Use of CAMEL Model: A Study on Financial Performance of Selected Commercial Banks in Bangladesh," Universal Journal of Accounting and Finance, Vol. 2, No. 5, pp.151-160.

Njoku, J. (2013), “Innovative determinants of Nigerian bank financial condition," African J. Accounting, Auditing and Finance, Vol. 2, No. 2, pp.91-113.

Nurazi, R. and Evans, M. (2005), "An Indonesian study of the use of CAMEL (S) ratios as predictors of bank failure," Journal of Economic and Social Policy, Vol. 10, No. 1, pp.6.

Prasuna, D.G. (2004), “Performance Snapshot 2003-04," Chartered Financial Analyst, Vol. 10, No. 11, pp.6-13.

Reddy, S.K. (2012), "Relative performance of commercial banks in India using CAMEL approach," International Journal of Multidisciplinary Research, Vol. 2, No. 3, pp.38-58.

Roman, A. and Şargu, A.C. (2013), "Analyzing the financial soundness of the commercial banks in Romania: an approach based on the camel's framework," Procedia economics and finance, Vol. 6, pp.703-712.

Said, R.M. and Tumin, M.H. (2011), "Performance and financial ratios of commercial banks in Malaysia and China," International Review of Business Research Papers, Vol. 7, No. 2, pp.157-169.

Sangmi, D.M. and Nazir, D. T. (2010), “Analyzing Financial Performance of Commercial Banks in India: Application of CAMEL Model," Pakistan Journal of Social Science, Vol. 4, No. 1, pp. 40-55.

Sarker, A. (2005), "CAMELS rating system in the context of Islamic banking: A proposed S for Shariah framework," Journal of Islamic Economics and Finance, Vol. 1, No. 1, pp.78-84.

Siva, S. and Natarajan, P. (2011), "Camel rating scanning (CRS) of SBI groups," Journal of Banking Financial Services and Insurance Research, Vol. 1, No. 7, pp.1-17. 
Tripathi, D., Meghani, K. and Mahajan, S. (2014), "Financial Performance Of Axis Bank And Kotak Mahindra Bank In The Post-Reform Era: Analysis On CAMEL Model," Economics and Applied Management Research, ISSN, pp.2349-5677.

Veni, P. (2004), "Capital adequacy requirement of commercial banks: A study in Indian Context," GITAM Journal of Management, Vol. 2, No. 2, pp.99-107.
Wirnkar, A.D. and Tanko, M. (2008), "CAMELS and banks performance evaluation: The way forward," available at SSRN 1150968 (accessed 25 March 2015).

$--0-$

\section{SOCIAL SCIENCE RESEARCH NETWORK 2171 Monroe Avenue, Suite 203, Rochester, NY 14618, USA http://www.ssrn.com/en/}

AJTP Link: http://www.ssrn.com/link/American-Journal-Trade-Policy.html 